\title{
Editorial
}

\section{Corporate governance of financial institutions}

The importance of effective corporate governance is evident when the history of the international capital markets is reviewed, as it demonstrates that a weak system of governance (eg in banks) increases the likelihood of financial fraud or loss. In the extreme case scenario, the fall-out from these failures may have wider systemic consequences, with a significant risk of contagion in the banking system. Banks as financial intermediaries in capital markets require investor and depositor confidence as a whole. Incidents such as large-scale corporate failure can occasionally undermine this by calling into question the overall wellbeing of others in the market place and adversely affecting investor confidence. In the light of this, bank supervisors have, over a considerable period of time, placed a significant amount of emphasis on mechanisms to ensure effective corporate governance in regulated firms to reduce the likelihood of risks becoming unmanageable.

This double issue of the Journal of Banking Regulation (JBR) marks the publication of some of the papers presented at the 'Corporate Governance of Financial Institutions' conference organised by the Society for Advanced Legal Studies, sponsored by Oxford Brookes University in association with the JBR and held at Charles Clore House on 7-8 October,
2004. The conference attracted speakers from a number of countries and was pleased to welcome Ross Delston and Nancy Rawlings from the International Monetary Fund, and Dr Eva Hüpkes of the Swiss Federal Banking Commission.

The two day conference examined topics such as Basel II, the law and economic perspective, the experience of developed, emerging market and developing economies' adoption of a corporate governance regime, stakeholder interests and mechanisms to ensure accountability of financial institutions.

\section{Professor Edward Cahill}

We must end on a sad note with the news that, while this issue was in production, one of its contributors, Professor Edward Cahill, passed away on 28th November 2005. Professor Cahill was keen that his paper 'Audit committee and internal audit effectiveness in a multinational bank subsidiary: A case study' be published in the Journal, and we are pleased to fulfil his wish here. This issue of the Journal of Banking Regulation is dedicated to him.

\section{Dr Dalvinder Singh \\ IALS Editor \\ December 2005}

Journal of Banking Regulation, Vol. 7 , Nos. $1 / 2$ 2006, p. 1

(C) Palgrave Macmillan Ltd, $1745-6452 / 06 \$ 30.00$ 